HANSEN, M.F. \& CoYe, R.D. (1961) Congenital nephrosis with renal arteriolar hypertrophy. American Journal of Diseases of Children, 105, 338.

Hoyer, J.R., Michael, A.F., Good, R.A. \& Vernier, R.L. (1967) The nephrotic syndrome of infancy: clinical, morphologic and immunologic studies of four infants. Pediatrics, 40, 233.

Kobayashi, N. (1966) An immunochemical study on renal biopsies in children. Archives of Diseases in Childhood, 41, 477.

lange, K., Wachstein, M., Wasserman, E., Alptekin, F. \& Slobody, L.B. (1963) The congenital nephrotic syndrome, an immune reaction? American Journal of Diseases of Children, 105, 338.
McDonald, R., Wiggelinkhuizen, J. \& Kashula, R. Ф (1971) The nephrotic syndrome in very young infants. American Journal of Diseases of Children, 122, 507.

NoRIO, R. (1966) Heredity in the congenital nephrotic syndrome. Annales paediatriae Fenniae, 12 (Supplement 27), 12.

Norio, R., Huolt, L. \& Hallman, N. (1964) Congenital nephrotic syndrome. An inherited disease? Annales paediatriae Fenniae, 10, 223.

Parker, R.A. \& Piel, C.F. (1960) The nephrotic syndrome in the first year of life. Pediatrics, 25, 967.

Vernier, R.L., Brunson, J. \& Good, R.A. (1957) Studies on familial nephrosis: I. Clinical and pathological study of four cases in a single family. American Journal of Diseases of Children, 93, 469.

\title{
Lead poisoning with low blood lead levels
}

\author{
P. TORKINGTON* \\ M.A., M.B., M.R.C.P. \\ Division of Metabolism, \\ The Royal Infirmary, Manchester
}

\section{Summary}

Two cases are reported in which symptomatic lead poisoning coincided with normal haemoglobin concentrations and blood lead levels below $80 \mu \mathrm{g} / 100 \mathrm{ml}$. Urinary coproporphyrins and amino laevulinic acid concentrations were elevated. These latter tests are useful for confirmation of clinical diagnoses and for the screening of industrial lead workers.

\section{Introduction}

A lead hazard exists in many industries and even where protective measures are enforced, workers have shown indices of exposure only just below danger levels (Gibson, Mackenzie and Goldberg, 1968). Several tests are available for detecting those in danger of becoming intoxicated. Measurements of blood lead and haemoglobin concentration are widely used for such screening. Two cases are described to draw attention to the limitations of these particular tests whether used in a prophylactic capacity in industry or to confirm clinical lead poisoning.

\section{Methods}

Blood and urinary lead concentrations were measured by E. King of National Occupational Hygiene Services using the classical monocolour di-

\footnotetext{
* Present address: Department of Medicine, Sydney Hospital,
} Sydney, N.S.W. 2001, Australia.

\author{
K. K. BHALla \\ M.D. (LuCKNOW), M.R.C.P. \\ Bury General Hospital
}

thizone technique (King and Thompson, 1961) Within the relevant range of blood lead concentrations, $50-100 \mu \mathrm{g} / 100 \mathrm{ml}$ whole blood, results are accurate to within $\pm 5 \mu \mathrm{g}$.

\section{Case 1}

A 20-year-old man mixed lead sulphate and lead stearate powders in the manufacture of plastics. An extractor fan was ineffective. Dust readily penetrated his gauze mask. Within 3 weeks of starting the job he developed central abdominal, colicky pain; this was quickly followed by vomiting. The condition was not recognized and after a week at home he resumed work. Within $3 \mathrm{hr}$ he was prostrated by abdominal colic. He was admitted to hospital the next day; at that time the haemoglobin was $14.2 \mathrm{~g} / 100 \mathrm{ml}$ and the blood lead $75 \mu \mathrm{g} / 100 \mathrm{ml}$. The pains diminished over a period of 4 days. Four weeks later at outpatients, the blood lead was $73 \mu \mathrm{g} / 100 \mathrm{ml}$. Against advice, he again resumed work. Within 3 weeks he was re-admitted to hospital, the symptoms had recurred. Vomiting started at the onset of the abdominal colic; it was intractable and was evoked by any oral food or fluid for 3 days after the colic had ceased. He also complained of postural dizziness, parasthesiae in the hands and face and that 'the use had gone out of his legs'. Examination revealed an ill-defined blue line on the upper gum which had disappeared within 5 days but there was no neurological abnormality. 
The results of the investigations performed during this second hospital admission are tabulated. After discharge he changed his work and has since been well. Biochemical results obtained at follow up 1 year later are tabulated. The blood lead had fallen to $27 \mu \mathrm{g} / 100 \mathrm{ml}$. Erythrocyte protoporphyrin and urinary amino laevulinic acid levels had fallen appreciably but had not reached the normal range. Other results were normal. The time-course of the biochemical recovery in this patient is typical of lead intoxication.

\section{Case 2}

This man was 23 years old. He smeared a paste of inorganic lead salts on to a metal grid in the manufacture of lead-acid batteries and had been doing this work for 2 years. A routine check in 1971 showed him to have a blood lead of $86 \mu \mathrm{g} / 100 \mathrm{ml}$. He consulted the factory doctor in September 1972 because of intermittent abdominal pains, constipation and general lethargy and the lead concentration was $76 \mu \mathrm{g} / 100 \mathrm{ml}$. He was referred to hospital. Considerable domestic stress was evident and made interpretation of his symptoms uncertain. Barium $\mathrm{X}$-ray studies revealed no abnormalities. The results of the laboratory tests are tabulated.

On advice, he was 'removed from exposure to lead' to another part of the factory. Two weeks later his complaints and the blood lead figure were unchanged but thereafter he became symptom-free. However, investigations 4 months later showed a slight fall in haemoglobin concentration and other evidence of persisting intoxication (see Table 1). Enquiry revealed that he was handling dried lead plates and thus was probably still occupationally exposed.

\section{Discussion}

In both cases, laboratory tests showed abnormalities consistent with the clinical suspicion of lead poisoning. The possibility of acute intermittent porphyria was considered in view of the evident disturbance of porphyrin metabolism but was ruled out by the absence of neurological or psychiatric manifestations, the absence of porphobilinogen from the urine and the marked increases in erythrocyte protoporphyrin. A co-worker of case 1 was twice admitted to hospital because of colic and vomiting within the space of 3 months. On the second occasion, the diagnosis of acute lead poisoning was made, the haemoglobin being $9.0 \mathrm{~g} / 100 \mathrm{ml}$, the blood lead $170 \mu \mathrm{g} / 100 \mathrm{ml}$ (corrected for the low haematocrit) and the urinary coproporphyrins $600 \mu \mathrm{g} / \mathrm{l}$. Bouts of acute illness recurring with re-exposure to lead and ceasing once exposure ceased, together with evidence of similar intoxication in a colleague would seem to put the diagnosis in case 1 beyond doubt. In the second case, it is not possible to be certain that the non-specific symptoms complained of were the result of lead poisoning but such a diagnosis seems the only reasonable explanation for the disturbance of porphyrin metabolism.

Lane and his co-authors (1968) classified lead absorption from occupational exposure as acceptable, excessive or dangerous and defined for several laboratory tests, values they considered characteristic of each level of absorption. Blood lead concentrations of up to $80 \mu \mathrm{g} / 100 \mathrm{ml}$ were regarded as consistent with acceptable absorption; and, although the authors did not intend that this figure should be used in isolation, it has been applied in the screening of industrial workers as an arbiter of safety. The

TABLE 1. Lead poisoning with low blood lead levels; results of laboratory tests

\begin{tabular}{|c|c|c|c|c|c|}
\hline \multirow[b]{2}{*}{ Interval between investigation and last exposure (days) } & \multicolumn{2}{|c|}{ Case 1} & \multicolumn{2}{|c|}{ Case 2} & \multirow[t]{2}{*}{ Normal range } \\
\hline & 3 & 350 & 1 & $? 120^{*}$ & \\
\hline $\begin{array}{l}\text { Haemoglobin } \\
\mathrm{g} / 100 \mathrm{ml}\end{array}$ & $13 \cdot 9$ & $14 \cdot 6$ & $15 \cdot 4$ & $13 \cdot 6$ & $13 \cdot 5-18 \cdot 0$ \\
\hline $\begin{array}{l}\text { Blood lead } \\
\mu \mathrm{g} / 100 \mathrm{ml} \text { whole blood }\end{array}$ & 69 & 27 & 70 & 63 & $<40$ \\
\hline $\begin{array}{l}\text { Urinary lead (urine S.G.) } \\
\mu \mathrm{g} / \mathrm{l}\end{array}$ & $310(1012)$ & $7(1011)$ & $288(1021)$ & $210(1022)$ & $<80$ \\
\hline $\begin{array}{l}\text { Erythrocyte protoporphyrin } \\
\mu \mathrm{g} / 100 \mathrm{ml} \text { whole blood }\end{array}$ & 524 & 162 & 341 & 497 & $15-40$ \\
\hline $\begin{array}{l}\text { Erythrocyte } \delta \text { amino laevulinic acid dehydrogenase } \\
\text { i.u. } / \mathrm{ml}\end{array}$ & - & - & 12 & 13 & $28 \pm 11$ \\
\hline $\begin{array}{l}\text { Urinary coproporphyrin } \\
\mu \mathrm{g} / \mathbf{l}\end{array}$ & 1570 & 70 & 1720 & 1460 & $70-250$ \\
\hline $\begin{array}{l}\text { Urinary } \delta \text { amino laevulinic acid } \\
\mathrm{mg} / 100 \mathrm{ml}\end{array}$ & $8 \cdot 0$ & $0 \cdot 8$ & $3 \cdot 0$ & $5 \cdot 0$ & $0.1-0.7$ \\
\hline $\begin{array}{l}\text { Urinary porphobilinogen } \\
\text { (qualitative test) }\end{array}$ & Absent & Absent & Absent & Absent & \\
\hline
\end{tabular}

* Probably still exposed to lead, see text, though he claimed not to have been at risk for 4 months. 
cases we report had blood lead values below $80 \mu \mathrm{g} /$ $100 \mathrm{ml}$ yet both cases were unequivocally suffering from lead poisoning. In addition, both cases had normal haemoglobin concentrations and so would have escaped detection by screening programmes based on the usual haemoglobin or blood lead criteria. Similar cases have been reported (Waldron, 1971; Gibson et al., 1968) and the latter authors recommended that lead concentrations greater than $60 \mu \mathrm{g} / 100 \mathrm{ml}$ should prompt further investigation.

Lead in the blood reflects absorption of the metal. Individuals vary in their susceptibility to intoxication and in practice, indices of absorption do not correlate closely with indices of intoxication (Gibson et al., 1968). It, therefore, seems logical to prefer evidence of intoxication to estimates of absorption both for occupational screening and for confirmation of clinical diagnoses. Of the investigations tabulated for these patients, the measurement of erythrocyte protoporphyrin is too difficult and that of $\delta$-amino laevulinic acid dehydrogenase activity too sensitive (Hernberg and Nikkanen, 1970) for routine use. Regular haemoglobin determinations in all statutory lead workers are required by law (Ministry of Labour, 1965). A decrement in haemoglobin concentration is evidence of significant lead poisoning, other causes having been excluded, but as shown in this report, symptomatic poisoning may coincide with normal haemoglobin values. Measurements of urinary amino laevulinic acid and urinary coproporphyrins are useful in both the industrial and the clinical context (Gibson et al., 1968; Haeger-
Aronsen, 1971). Their sensitivity is such that they become abnormal at an early stage of lead intoxication. Had our cases presented for routine occupational screening, both urinary coproporphyrin and amino laevulinic acid measurements would have recognized a state of lead poisoning; neither haemoglobin nor blood lead measurements would have recognized it.

\section{Acknowledgments}

Our thanks are due to Dr R. S. Savidge of Bury General Hospital and Professors W. R. Lee and S. W. Stanbury of Manchester University for permission to report these cases. Professor Lee and Dr P. H. Adams are responsible for many improvements in the final manuscript. We are grateful to Dr D. Walsh and the technicians of the Manchester Royal Infirmary laboratories for the chemical estimations.

\section{References}

Gibson, S.L.M., Mackenzie, J.C. \& Goldberg, A. (1968) The diagnosis of industrial lead poisoning. British Journal of Industrial Medicine, 25, 40.

HAEGER-ARONSEN, B. (1971) An assessment of the laboratory tests used to monitor the exposure of lead workers. British Journal of Industrial Medicine, 28, 52.

Hernberg, S. \& NikKanen, J. (1970) Enzyme inhibition by lead under normal urban conditions. Lancet, $\mathbf{i}, 63$.

KING, E. \& Thompson, A.R. (1961) The measurement of lead absorption in industry. Annals of Occupational Hygiene 3, 247.

LANE, R.E., ETAL (1968) Diagnosis of inorganic lead poiso ing: a statement. British Medical Journal, 4, 501.

Ministry OF LABOUR (1965) Annual Report of H.M. Chis Inspector of Factories in Industrial Health, 1964. H.M.S.O., London.

WALDRON, H.A. (1971) Correlation between some parameters of lead absorption and lead intoxication. British Journal of Industrial Medicine, 28, 195.

\title{
Acute barbiturate poisoning in young epileptics
}

\author{
B. W. HANCOCK \\ M.B., CH.B., D.C.H. \\ Neurology Unit, Fulwood Annexe, Sheffield
}

\begin{abstract}
Summary
Two young epileptic patients presenting in coma with focal neurological signs were found to be suffering from unsuspected acute barbiturate overdose. There had been strenuous denial of any possibility of psychiatric disturbance or of self-poisoning in the history obtained from their parents at the time of admission. The importance of excluding deliberate drug overdose in any young epileptic patient presenting with prolonged or atypical coma is re-emphasized.
\end{abstract}

Correspondence: B. W. Hancock, 42 Winchester Road, Sheffield S10 4EE.
COMA is a common presentation of the known $N$ epileptic patient to the acute medical unit. The following two cases are reported to emphasize the $O$ importance of excluding deliberate drug overdose in $\mathrm{\omega}$ the young epileptic patient whose presenting coma is in any way atypical or prolonged.

\section{Case 1}

A 12-year-old girl with a 2-year history of Grand Mal epilepsy was admitted to the Neurology Unit $\underset{\mathbb{D}}{\stackrel{0}{D}}$

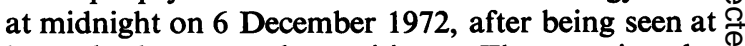
home by her general practitioner. That evening she 